\title{
SYNTHESIS AND CHARACTERIZATION OF BENZOTRIAZOLIUM-BASED IONIC LIQUIDS FOR TECHNETIUM-99M SEPARATION FROM MOLYBDENUM BY IL-MEDIATED EXTRACTION PROCESS
}

\author{
Yanuar Setiadi', Muhamad Basit Febrian'1, Ahmad Mudzakir², Azmairit Aziz', Duyeh \\ Setiawan' ${ }^{1}$, A. K. Illahi ${ }^{3}$, D. A. Rahmawati ${ }^{3}$ \\ 1) Center for Applied Nuclear Science and Technology, National Nuclear Energy Agency \\ Jalan Tamansari 71, Bandung 40132, Indonesia \\ 2) Chemistry Education Department, Indonesia University of Education \\ JI. Dr. Setiabudi No. 229 Bandung 40381, Indonesia \\ 3) Chemical Analysis Department, State Polytechnic of Bandung \\ Gegerkalong Hilir, Bandung 40012, Indonesia \\ Email: yanuar-setiadi@batan.go.id
}

Diterima : 12-09-2019

Diterima dalam bentuk revisi: 16-09-2019

Disetujui: 12-10-2019

\begin{abstract}
SYNTHESIS AND CHARACTERIZATION OF BENZOTRIAZOLIUM-BASED IONIC LIQUIDS FOR TECHNETIUM-99M SEPARATION FROM MOLYBDENUM BY IL-MEDIATED EXTRACTION PROCESS. Various separation techniques for separation of technetium-99m $\left({ }^{99 \mathrm{~m} T c}\right)$ from molybdenum-99 $\left({ }^{99} \mathrm{Mo}\right)$ are being developed to overcome the drawbacks of using ${ }^{99} \mathrm{Mo} \mathrm{from} \mathrm{neutron} \mathrm{activation} \mathrm{technique.} \mathrm{Ionic} \mathrm{liquids} \mathrm{(ILs)} \mathrm{were} \mathrm{used} \mathrm{in} \mathrm{many} \mathrm{extraction} \mathrm{processes}$ in metal separation due to their high selectivity. In this research, two benzotriazolium-based ionic liquids were used as co-extractant in ${ }^{99 \mathrm{~m}} \mathrm{Tc} / \mathrm{Mo}$ separation process via liquid-liquid extraction. 1octyl-3-methyl-benzotriazolium iodide ([MeOcBtu]l) and 1-octyl-3-methyl-benzotriazolium bis (trifluoromethanesulfonyl) imide ([MeOcBtu]TF${ }_{2} \mathrm{~N}$ ) were successfully synthesized and analyzed by FTIR, ${ }^{1} \mathrm{H}$-NMR and ${ }^{13} \mathrm{C}$-NMR. Extraction processes were conducted in various organic solvents, $\mathrm{pH}$, and extraction time without/ with ionic liquids addition. The data of ratio between ${ }^{99 \mathrm{~m} T \mathrm{Tc}}$ distribution coefficient compared to Mo distribution coefficient showed that the addition of ionic liquids exhibited significant improvement of separation factor. The separation factor of extraction using conventional water immiscible solvent ranged between $0-8$ and increased to $30-600$ as ILs were added. The optimum conditions which achieved highest separation factor were pH 14 using [MeOcBtu]l-chloroform. Benzotriazolium-based ionic liquid potential to be developed as extractant in the separation of ${ }^{99 \mathrm{~m} T c}$ from ${ }^{99} \mathrm{Mo}$.
\end{abstract}

Keywords: Ionic liquids, benzotriazolium, technetium-99m, molybdenum, liquid-liquid extraction.

\begin{abstract}
ABSTRAK
SINTESIS DAN KARAKTERISASI CAIRAN IONIK BERBASIS BENZOTRIAZOLIUM UNTUK PEMISAHAN TEKNESIUM-99M DARI MOLYBDENUM MELALUI PROSES EKSTRAKSI. Berbagai teknik pemisahan teknesium-99m $\left({ }^{99 \mathrm{mTC}}\right)$ dari molybdenum-99 $\left({ }^{99} \mathrm{Mo}\right)$ telah dikembangkan untuk mengatasi kelemahan penggunaan ${ }^{99}$ Mo yang dihasilkan melalui teknik aktivasi neutron. Cairan ionik (IL) telah banyak digunakan dalam pemisahan logam melalui ekstraksi karena selektivitasnya yang tinggi. Dalam penelitian ini, dua cairan ionik berbasis benzotriazolium digunakan sebagai ko-ekstraktan dalam proses pemisahan ${ }^{99 \mathrm{mT}} \mathrm{Tc}$ Mo melalui ekstraksi cair-cair. 1-oktil-3-metil-benzotriazolium iodide ([MeOcBtu]l) dan 1-oktil-3-metilbenzotriazolium bis (trifluoromethanesulfonyl) imide $\left([\mathrm{MeOcBtu}] \mathrm{TF}_{2} \mathrm{~N}\right)$ berhasil disintesis dan dianalisis menggunakan FTIR, ${ }^{1} \mathrm{H}-\mathrm{NMR}$ dan ${ }^{13} \mathrm{C}-\mathrm{NMR}$. Proses ekstraksi dilakukan dalam berbagai pelarut organik, $\mathrm{pH}$, dan waktu ekstraksi tanpa/ dengan penambahan cairan ionik. Data rasio antara koefisien distribusi ${ }^{99 \mathrm{~m} T c}$ dengan koefisien distribusi Mo menunjukkan bahwa penambahan cairan ionik dalam sistem ekstraksi meningkatkan faktor pemisahan secara
\end{abstract}


signifikan. Faktor pemisahan ekstraksi menggunakan pelarut tak larut air berkisar antara 0 - 8 dan meningkat menjadi 30 - 600 ketika cairan ionik ditambahkan. Kondisi optimum untuk mencapai faktor pemisahan tertinggi adalah proses pada $\mathrm{pH} 14$ menggunakan pelarut [MeOcBtu]l-kloroform. Cairan ionik berbasis benzotriazolium mempunyai potensi untuk dikembangkan sebagai ekstraktan dalam proses pemisahan ${ }^{99 \mathrm{~m} T c}$ dari ${ }^{99} \mathrm{Mo}$.

Kata kunci : Cairan ionik, benzotriazolium, teknesium-99m, molibdenum, ekstraksi cair-cair

\section{INTRODUCTION}

Ionic liquids (ILs) are organic salts that consist entirely of ions which are liquids at room temperature (room temperature ionic liquids/ RTILs) or whose melting point is below $100^{\circ} \mathrm{C}$ (1). They may be differentiated from inorganic molten salts by their melting points. ILs have been broadly investigated as solvent for synthesis, separation techniques, catalysis and engineering fluid because their unique properties. ILs have possibility to obtain desired physicochemical properties by fine-tune its cation or anion combinations (2). These compounds also have several fascinating properties such as negligible vapor pressure, low flammability, high thermal stability, and broad electrochemical window and liquidus range (1). ILs offer promising possibility to be used in radioisotope separation through liquid-liquid extraction as extractant or as task-specific/ functionalized ionic liquids (TSIL) which have extraction ability by forming coordinated compound between particular metal ions and functional groups on their cation or anion.

The finest separation techniques for technetium-99m from molybdenum produced by neutron activation still needs to be developed. Technetium-99m generators commonly used today is chromatography systems using alumina as stationary phase. This method has the advantage of easy operation, high elution efficiency, and high radionuclide purity. However, the limitation of this system is capacity the alumina to absorb molybdenum which is about $2-20 \mathrm{mg} \mathrm{Mo} / \mathrm{g}$ alumina) (3)(4). Thus, this technique only performs well for high specific activity of molybdenum-99 which is produced from fission product of HEU (High Enriched Uranium).

The molybdenum-99 production via neutron activation becomes important issue since some of nuclear reactors which supplies molybdenum-99 (almost $90 \%$ of the world demand) are approaching decommissioning time and requires intensive maintenance. The main nuclear reactors are National Research Universal (NRU), the High Flux Reactor (HFR), BR-2, OSIRIS, and SAFARI-1 (5). Moreover, the issue of nuclear non-proliferation restrictions related to the elimination of the use of HEU grow into a major concern on the reliability and consistency in the supply of molybdenum-99 (4). This condition would affect the management of patients in various countries.

The thermal neutron cross section of the ${ }^{98} \mathrm{Mo}(\mathrm{n}, \mathrm{y}){ }^{99} \mathrm{Mo}$ reaction is just 0.136 barns, and hence the production of high specific activities of ${ }^{99} \mathrm{Mo}$ cannot be obtained (6). Radioactivity of molybdenum-99 produced from irradiated natural molybdenum is approximately $300-1000 \mathrm{mCi} /$ 
g, much lower than the fission of HEU that can reach $104 \mathrm{Ci} / \mathrm{g}$. Consequently, massive alumina is needed to absorb molybdenum and the system becomes less efficient for producing technetium-99m. Other techniques were introduced including extraction, electrodeposition, and other chromatography systems. One of the technetium-99m production technologies from irradiated natural molybdenum is extraction using methyl ethyl ketone. However, this technology is not practical for large scale production.

Water immiscible ionic liquids are required to extract technetium-99m from aqueous solution. Hydrophobic ionic liquid can be made by using long alkyl chain of cation and or using fluorinated anions such as bis(trifluoromethylsulfonyl)imide $\left(\mathrm{TF}_{2} \mathrm{~N}^{-}\right)$or hexafluorophosphate $\left(\mathrm{PF}_{6}^{-}\right)$(1). Long alkyl in 1-oktyl-3-methyl-benzotriazolium cation structure reduce its interaction with anion, thus ionic liquid based on this cation are liquid at room temperature and hydrophobic. In this research, room temperature ionic liquids based on this benzotriazolium cation were used to investigate their performance in liquid-liquid extraction for technetium-99m separation from molybdenum solution.

\section{EXPERIMENTAL SECTION}

\section{Synthetic Procedures}

The 1-methylbenzotriazole and benzotriazolium-based ionic liquids prepared in this work utilized the procedure described by Forsyth et al. (7) and Mudzakir et al. (8) with a slight development. 100 gram of $1 \mathrm{H}$ benzotriazole $(0.84 \mathrm{~mol})$ was dissolved in a
$300 \mathrm{~mL}$ solution of sodium hydroxide $5.6 \mathrm{M}$ (1.68 mol). $80 \mathrm{~mL}$ of dimethyl sulfate $(0.84$ mol) was added and the solution was stirred overnight at room temperature. This process formed two solution phases. The organic layer (brown solution) was separated from aqueous layer and extracted by hydrochloric acid $0.1 \mathrm{M}(\mathrm{pH} 1)$. The acidic aqueous layer was evaporated over $100^{\circ} \mathrm{C}$ to dryness and 1-methylbenzotriazole crystal (slightly brown) formed. Recrystallisation from hexane gave colorless needles of 1-methylbenzotriazole (melting point $59-62^{\circ} \mathrm{C}$ ). Melting point of 1 methyl benzotriazolium were performed by using melting point apparatus (Fisher Scientific 12144-1). FTIR (KBr, cm-1): 3468 w, 3088 w, 3051 m, 2947 m, 2358 m, 2332 w, 1902 w, 1782 w, 1682 w, 1610 m, 1591 m, 1495 m, 1452 m, 1419 w, 1383 m, 1348 m, 1300 m, 1265 m, 1196 s, 1159 m, 1119 m, 1020 s, 1001 m, 935 m, 773 m, 739 s, 661 m, $584 \mathrm{~m}$.

$20 \mathrm{~mL}$ octyl iodide $(200 \mathrm{mmol})$ was added to a solution of 1-methylbenzotriazol (10 gram, $75 \mathrm{mmol}$ ) in acetonitrile and refluxed overnight at $85^{\circ} \mathrm{C}$. The crude reaction mixture was evaporated to obtain a viscous yellowish liquid of 1-octyl-3-methylbenzotriazolium iodide/ [MeOcBtu]l. FTIR (KBr, cm-1): 3450 m, 2925 s, 2854 s, 1608 m, 1500 w, 1462 m, 1402 w, 1366 w, 1273 m, 1203 w, 1175 w, 1144 w, 1080 w, 1018 w, 959 w, 918 w, 777 s, 756 s, 725 w, 633 w. ${ }^{1} \mathrm{H}-$ $\operatorname{NMR}\left(\mathrm{CDCl}_{3}, 400 \mathrm{MHz}\right): \delta(\mathrm{ppm})=8.41(\mathrm{t}, 1 \mathrm{H}$ ring); 8.29 (t, $1 \mathrm{H}$ ring); 7.90 (m, 2H ring); 5.02 (t, $\left.2 \mathrm{H}, \mathrm{N}-\mathrm{CH}_{2}-\mathrm{R}\right) ; 4.76$ (s, 3H, N-CH $) ; 1.30$ (m, 12H, R-CH $-\mathrm{R}$ ); 0.82 (t, 3H, R-CH $\left.{ }_{3}\right) .{ }^{13} \mathrm{C}-$ $\operatorname{NMR}\left(\mathrm{CDCl}_{3}\right): \delta(\mathrm{ppm})=135.5 ; 134,9 ; 131.8$ 
(C-ring); 114.7; 113.9 (C-N); 53.0; 29.1; 28.9 (C-Alkyl).

For metathesis anion of ionic liquid, 3 grams of silver bis (trifluoromethanesulfonyl) imide $(7.7 \mathrm{mmol})$ was added to 2.6 grams of [MeOcBtu]l ionic liquid $(7 \mathrm{mmol})$ and the mixture was stirred for 1 hour at room temperature. This process resulted in a solution of 1-octyl-3-methyl-benzotriazolium bis (trifluoromethanesulfonyl) imide solution and a yellow sediment of silver iodide. Solid silver iodide was filtered and the methanol removed by rotary evaporation. The viscous yellowish liquid of $[\mathrm{MeOcBtu}] \mathrm{TF}_{2} \mathrm{~N}$ was produced then stored in aluminium foil closed container. FTIR (KBr, cm-1): $3450 \mathrm{w}, 2928 \mathrm{~m}$, 2858 m, 2395 w, 1763 w, 1609 w, 1500 w, 1462 w, 1431 w, 1379 m, 1354 w, 1277 w, 1227 w, 1194 s, 1138 m, 1059 s, 955 w, 826 w, 777 w, 752 m, 653 w, 617 m, 602 w, 570 $\mathrm{m}, 513 \mathrm{~m}$.

Structure analysis were performed by Fourier Transform Infra Red (Shimadzu IR Prestige-21) and ${ }^{1} \mathrm{H}-\mathrm{NMR}$ and ${ }^{13} \mathrm{C}-\mathrm{NMR}$ (Agilent).

\section{Ionic liquid-mediated Extraction Process} of ${ }^{99 m} \mathrm{Tc} / \mathrm{Mo}$

Technetium-99m as pertechnetate species was obtained from elution process to technetium generator by saline. $1 \mathrm{~mL}$ $\mathrm{Na}^{99 m} \mathrm{TcO}_{4}(\sim 100-1500 \mu \mathrm{Ci}) / \mathrm{Na}_{2} \mathrm{MoO}_{4}$ (1000 ppm) solutions were adjusted to varying $\mathrm{pH}$ and were added by an amount of [MeOcBtu]l (0.1 gram) and organic solvent as diluent up to total volume of $2 \mathrm{~mL}$. These mixtures were stirred with varying time. Ethyl acetate, chloroform and butanol were used as diluents for extraction process in ionic liquid. That organic solvents also were used as extractant in extraction process without the addition of ionic liquid for selectivity comparison.

The radioactivity of technetium-99m in each phase was measured using gamma spectrometer - multi channel analyzer (Canberra - DSA 1000) and the concentration of molybdenum was measured using spectrophotometer UV-Vis (Hitachi Model 200-20) through thiocyanate method. Liquid-liquid extractions of ${ }^{99 \mathrm{~m}} \mathrm{Tc} /$ Mo solution were processed using [MeOcBtu]l and $[\mathrm{MeOcBtu}] \mathrm{TF}_{2} \mathrm{~N}$ at optimum parameters.

\section{RESULTS AND DISCUSSION}

Distribution profiles of ${ }^{99 m} \mathrm{TC}$ and Mo on water immiscible conventional solvent

Liquid-liquid extraction is the separation and purification techniques based on the distribution differences of the solute between two immiscible phases. The solvent is the key of the extraction process. Distribution coefficient $(\mathrm{Kd})$ and selectivity/ separation factor $(\alpha)$ is one of important criteria in solvent selection.

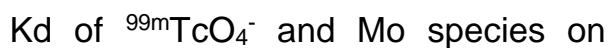
several conventional water-immiscible solvents were determined. Figure 1a show that the $\mathrm{Kd}$ of ${ }^{99} \mathrm{mcO}_{4}{ }^{-}$and $\mathrm{MoO}_{4}{ }^{2-}$ in liquidliquid extraction using butanol, ethyl acetate, and chloroform are below 0.6. These values are much lower than using MEK as extractant by the same procedure, which has $\mathrm{Kd}$ of ${ }^{99 \mathrm{~m}_{\mathrm{CCO}}}{ }_{4}^{-}$around 3.621. However, it was difficult to separate organic phase (MEK) from aqueous phase. This research used organic solvent which has lower solubility in water to reduce an error on phase separation 
Synthesis and Characterization of Benzotriazolium-Based lonic Liquids for

Technetium-99m Separation from Molybdenum by IL-Mediated Extraction

to get better information of the effect of ILs to $\mathrm{Kd}$ and $\alpha$ of the extraction.

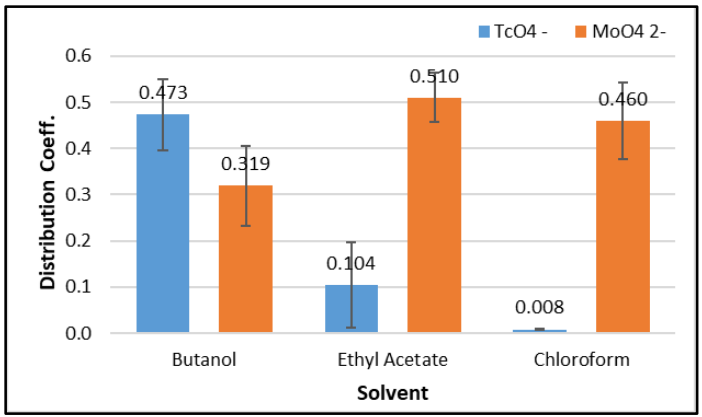

(a)

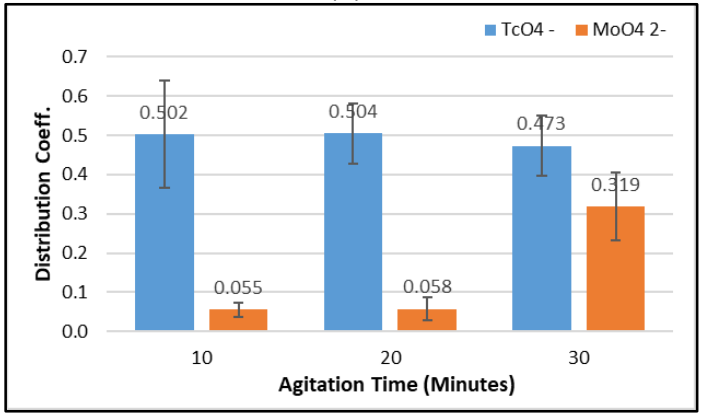

(b)

Figure 1. Distribution coefficient of $99 \mathrm{mTcO}_{4}^{-}$and $\mathrm{MoO}_{4}{ }^{2-}$ on (a) various solvent, $\mathrm{pH} \mathrm{14,} 30 \mathrm{~min}$, and (b) butanol, $\mathrm{pH} 14$, various agitation time

The highest separation factor of the solvent for ${ }^{99 m} \mathrm{TcO}_{4}^{-}$against $\mathrm{MoO}_{4}{ }^{2-}$ was achieved by using butanol as extractant $(\alpha=$ $1.531 \pm 0.200)$. Compared to other solvent, butanol extract ${ }^{99} \mathrm{TcO}_{4}^{-}$much higher. To obtain equilibrium in short time, agitation (stirring or shaking) are needed to increase the phase boundary area between two phases at which distribution of the solute occurs (9). Figure 1b displayed the equilibrium of ${ }^{99} \mathrm{TcO}_{4}^{-}$might completed below 10 minutes of agitation while equilibrium of $\mathrm{MoO}_{4}{ }^{2-}$ not yet reached. Separation factor was declined over time due to $\mathrm{MoO}_{4}{ }^{2-‘} \mathrm{~s} \mathrm{Kd}$ escalation. Lower agitation time provide better separation of ${ }^{99} \mathrm{TcO}_{4}$ from $\mathrm{MoO}_{4}{ }^{2-}$ whose $\alpha$ was $9.254 \pm 0.765$ at 10 minutes agitation.

On alkaline environment, molybdate species is only as $\mathrm{MoO}_{4}{ }^{2-}$. The potentiometric data analysis from Krishnan, et.al. (10), hepta-molybdate, $\mathrm{Mo}_{7} \mathrm{O}_{24}{ }^{6-}$ and their protonated species were formed in the $\mathrm{pH}$ range 4 to 6 and octa-molybdates, $\mathrm{Mo}_{8} \mathrm{O}_{26}{ }^{4-}$ was formed below pH 3.0. Each species might have different distribution on each phase and contribute to separation factor at selected $\mathrm{pH}$ as shown in Figure 2. Maximum separation factor was reached at $\mathrm{pH}$ extraction $5(\alpha=4.676 \pm 1.95)$ whereas distribution of Mo species on organic phase was in the lowest level. However, all this number of separation factor using those organic solvent was not sufficient for a good extraction process. Thus, to increase separation factor, benzotriazolium-based ionic liquid was added into the liquid-liquid extraction system.

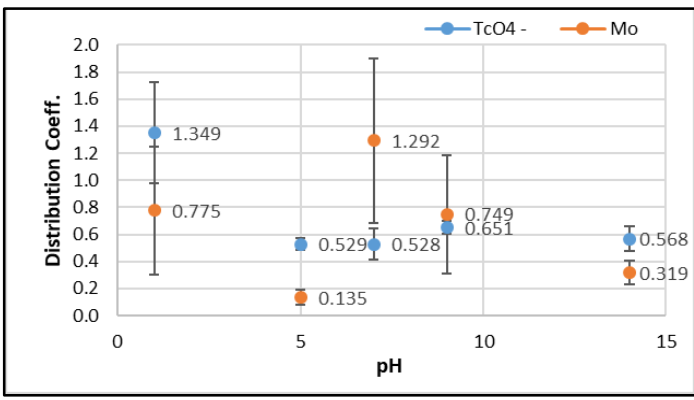

Figure 2. Distribution coefficient of $99 \mathrm{mTcO}_{4}^{-}$and Mo species under different $\mathrm{pH}$ (30 min, butanol)

\section{Distribution profiles of ${ }^{99 \mathrm{~m}} \mathrm{Tc} /$ Mo species on IL-mediated solvent}

Compared to organic solvent which has viscosity about $1 \mathrm{cP}$, ionic liquids have much higher viscosity that make difficulties to use ILs as diluents in extraction systems (9). 
For this reason, benzotriazolium-based ionic liquid was used in liquid-liquid extraction as co-extractant to surge distribution of technetium-99m on organic solvent.

An enormous improvement into technetium distribution occurred when using IL-mediated extraction while Mo's distribution was not significantly changed. Therefore, [MeOcBtu]l have major impact to selectivity of the separation process of technetium-99m from molybdenum. Remarkable value of distribution was reached when combination of chloroform and [MeOcBtu]l was used as organic phase as shown in Figure 3a. Extraction process using this extractant has selectivity of $128.80 \pm 4.36$.

Similar to the extraction process without ILs, the equilibrium of ${ }^{99 \mathrm{~m}} \mathrm{TcO}_{4}^{-}$was reached in very short time. However, equilibrium of $\mathrm{Mo}_{7} \mathrm{O}_{24}{ }^{6-}$ species might occurs at short time as well. In order to get the optimum extraction time for better separation, further research with shorter period of extraction are required. Figure $3 \mathrm{~b}$ illustrates that the effect of agitation time to separation factor using this separation system is unclear. Lower agitation time might provide better separation with separation value of $460.15 \pm$ 27.95 at 10 minutes agitation.

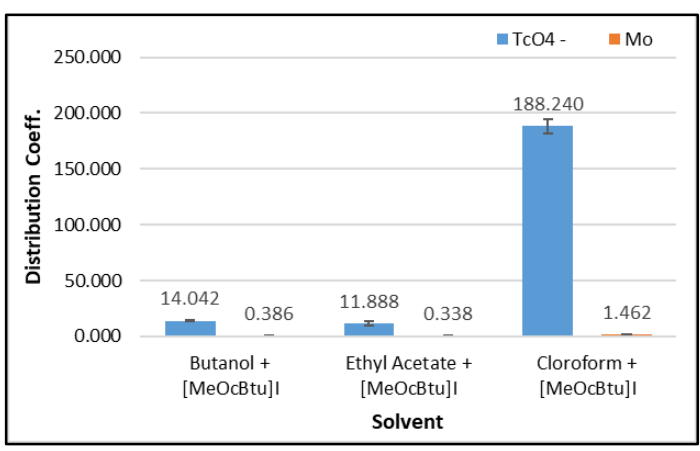

(a)

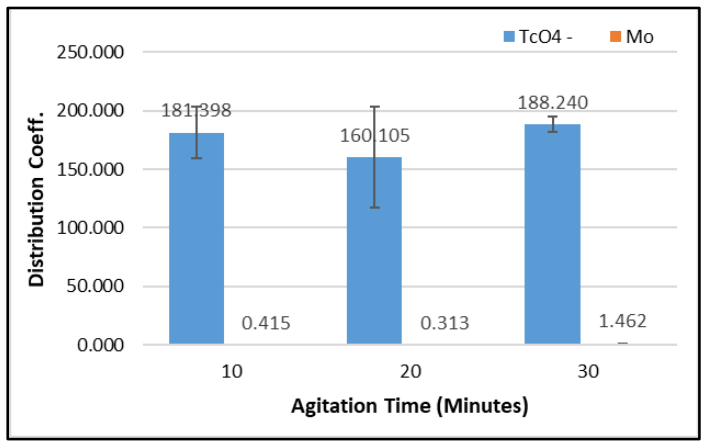

(b)

Figure 3. Distribution coefficient of $99 \mathrm{mTcO}_{4}^{-}$and $\mathrm{Mo}_{7} \mathrm{O}_{24}{ }^{6-}$ on (a) [MeOcBtu]l-mediated solvent, $\mathrm{pH}$ 5, $30 \mathrm{~min}$, and (b) chloroform + [MeOcBtu]l, $\mathrm{pH} 5$, various agitation time

Although distribution of ${ }^{99 \mathrm{~m}} \mathrm{TcO}_{4}{ }^{-}$at $\mathrm{pH}$ 5 was slightly higher than at $\mathrm{pH} 14$, distribution of Mo species in $\mathrm{Mo}_{7} \mathrm{O}_{24}{ }^{6-}$ form was much higher than $\mathrm{MoO}_{4}{ }^{2-}$ as shown in Figure 4. Thus, greatest separation using this system was conducted at $\mathrm{pH} 14$ with separation factor value as $523.53 \pm 43.10$.

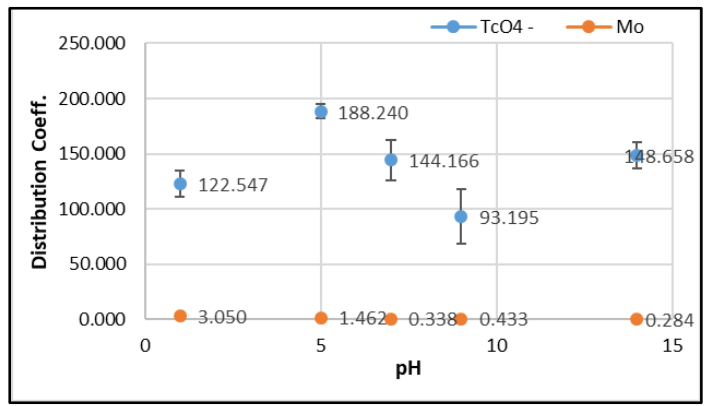

Figure 4. Distribution coefficient of ${ }^{99 m} \mathrm{TcO}_{4}{ }^{-}$and Mo species under different $\mathrm{pH}$ (30 min, chloroform $+[\mathrm{MeOcBtu}] \mathrm{l})$

Another aspect that might influence the effectivity of liquid-liquid extraction is the amount of ionic liquid (Figure 5a) and the type of ionic liquid (Figure $5 b$ ). It can be seen that there is an increase in $\mathrm{Kd}$ and a of each solute along with the amount of [MeOcBtu]l added. The use of bis(trifluoromethylsulfonyl)imide $\quad\left(\mathrm{TF}_{2} \mathrm{~N}^{-}\right)$ anion to replace $\mathrm{I}^{-}$in ionic liquid reduce 
viscosity of ionic liquid. However, its combination with chloroform does not offer better separation factor.

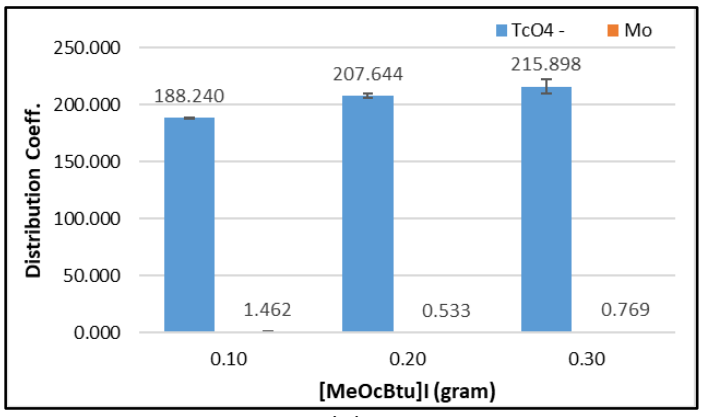

(a)

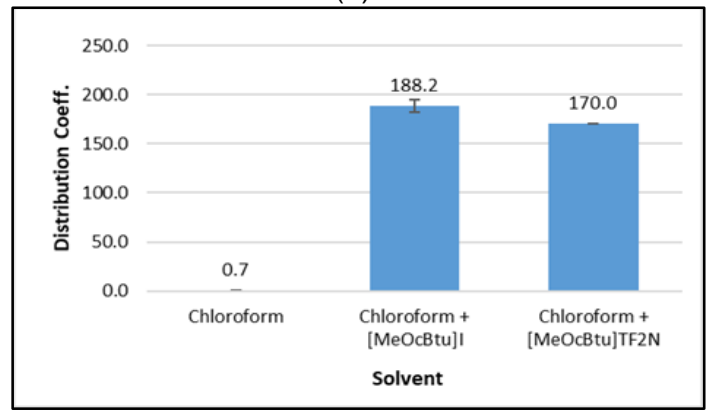

(b)

Figure 5. The effect of (a) mass, and (b) type, of ionic liquid used on $\mathrm{Kd}$ of $99 \mathrm{mTcO}_{4}{ }^{-}$

\section{CONCLUSION}

Benzotriazolium-based ionic liquid has considerable effect on distribution and separation factor of extraction system for technetium-99m production. The separation factor of extraction using conventional organic solvent ranged between $0-8$ and increased up to 600 as ILs were added. The optimum conditions to achived highest separation factor were $\mathrm{pH} 14$ using [MeOcBtu]l-chloroform as extractant. Further research to determine the optimum condition especially using shorter period of agitation and using another type of anion of benzotriazolium-based ionic liquid which has lower viscosity are still needed.

\section{ACKNOWLEDGEMENTS}

The authors would like to thanks to the Center for Applied Nuclear Science \& Technology, National Nuclear Energy Agency for financial support.

\section{REFERENCES}

1. Wellens S. Ionic Liquid Technology in Metal Refining : Dissolution of Metal Oxides and Separation by Solvent Extraction. KU Leuven; 2014. 1-100 p.

2. Wang W, Liu $Y, X u A$, Yang $H$, Cui $H$, Chen J. Solvent extraction of yttrium by task-specific ionic liquids bearing carboxylic group. Chinese J Chem Eng. 2012;20(1):40-6.

3. Chakravarty R, Dash A, Venkatesh M. A novel electrochemical technique for the production of clinical grade

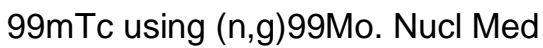
Biol. 2010;37(1):21-8.

4. Dash A, Knapp FF (Russ), Pillai MRA. 99Mo/99mTc separation: An assessment of technology options. Nucl Med Biol. 2013;40(2):167-76.

5. van der Marck SC, Koning AJ, Charlton KE. The options for the future production of the medical isotope 99Mo. Eur J Nucl Med Mol Imaging. 2010;37(10):1817-20.

6. Matyskin A V., Ridikas D, Skuridin VS, Sterba J, Steinhauser G. Feasibility study for production of $99 \mathrm{mTc}$ by neutron irradiation of MoO3 in a $250 \mathrm{~kW}$ TRIGA Mark II reactor. J Radioanal Nucl Chem. 2013;298:413-8. 
7. Forsyth SA, MacFarlane DR. 1-Alkyl-

3-methylbenzotriazolium salts: ionic

solvents and electrolytesElectronic

supplementary information (ESI)

available: complete experimental

procedures and spectroscopic data

for all compounds prepared. See

http://www.rsc.org/suppdata/jm/b3/b3

07931g/. J Mater Chem.

2003;13(10):2451 .

8. Mudzakir A, Aisyah S, Kadarohman

A, Anwar B, Setiadi Y. Garam 1,3-

Alkilmetil-1,2,3-benzotriazolium:

Sistem Pelarut lonik Baru pada

Proses Pelarutan dan Rekonstitusi

Selulosa. Chemica. 2009;10(2):1-13.

9. Vander Hoogerstraete T, Onghena B,

Binnemans K. Homogeneous liquid-

liquid extraction of rare earths with

the betaine-betainium

bis(trifluoromethylsulfonyl)imide ionic

liquid system. Int J Mol Sci.

2013;14(11):21353-77.

10. Krishnan C V, Garnett M, Hsiao B,

Chu B. Electrochemical

Measurements of

Isopolyoxomolybdates : $1 . \mathrm{pH}$

Dependent Behavior of Sodium

Molybdate. Int J Electrochem Sci.

2007;2:29-51. 